Destroy this report when no longer needed. Do not return it to the originator.

The findings in this report are not to be construed as an official

Department of the Army position unless so designated by other authorized documents. 


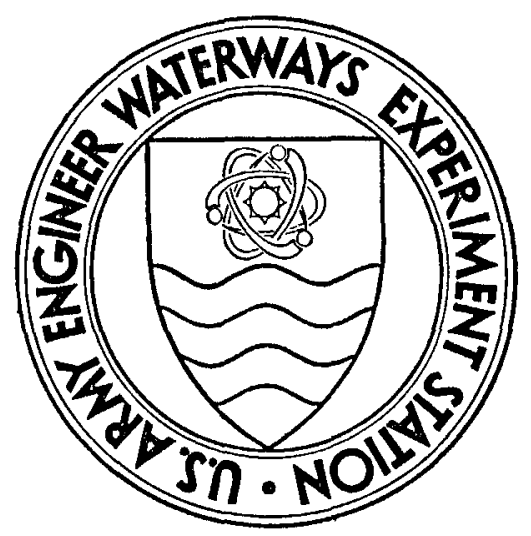

MISCELLANEOUS PAPER $M-73-2$

\section{POWER REQUIREMENTS FOR WHEELS OPERATING IN FINE-GRAINED SOILS}

by

K.-J. Melzer

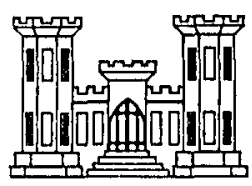

April 1973

Sponsored by U. S. Army Materiel Command

Project No. ITI62112A046, Task 03

Conducted by U. S. Army Engineer Waterways Experiment Station

Mobility and Environmental Systems Laboratory

Vicksburg, Mississippi 
W34 m

No. $m, ?-2$

$0,2,2$

\section{Foreword}

The study reported herein was conducted during 1972 by Dr. K.-J. Melzer of the Mobility Research Branch (MRB), Mobility and Environmental Systems Laboratory (MESL), U. S. Army Engineer Waterways Experiment Station (WES), in furtherance of DA Project IT1621.12A046, "Trafficability and Mobility Research," Task 03, "Mobility Fundamentals and Model Studies," sponsored by the Research, Development and Engineering Directorate, U. S. Army Materiel Command. It was a desk study of data collected in previous mobility research investigations performed at WES.

The work was performed under the general supervision of Mr. W. G. Shockley, Chief, MESL, and under the direct supervision of Messrs. S. J. Knight and C. J. Nuttall, Jr., former Chief and present Chief, MRB, respectively. Dr. Melzer was assisted in the analysis of the data by Miss M. E. Smith and in the writing of the report by Mrs. M. L. Doiron, both of MRB.

COL Ernest D. Peixotto, CE, was Director of WES during this study and preparation of the report. Mr. F. R. Brown was Technical Director. 



\section{Contents}

$\underline{\text { Page }}$

Foreword . . . . . . . . . . . . . . . . . . . . iii

Conversion Factors, Metric to British and British to Metric

Units of Measurement . . . . . . . . . . . . . . vii

Summary . . . . . . . . . . . . . . . . . . . . . ix

Introduction . . . . . . . . . . . . . . . . . . . . II

Basic Concept . . . . . . . . . . . . . . . . . . . I I

Development of Expanded Prediction System . . . . . . . . 6

Application of Prediction System to Vehicle Field Data . . . . . Il

M35A2 truck . . . . . . . . . . . . . . . . 11

MEXA 10XI0 vehicle ................. . . . 14

MEXA 8x8 vehicle .................... . . . . . 14

Conclusions and Recommendation . . . . . . . . . . . . 15

Literature Cited. . . . . . . . . . . . . . 16 

Conversion Factors, Metric to British and British to Metric Units of Measurement

Metric units of measurement used in this report can be converted to British units as follows:

\begin{tabular}{lll}
\multicolumn{1}{c}{ Multiply } & \multicolumn{1}{c}{ By } & \multicolumn{1}{c}{ To Obtain } \\
\cline { 2 - 3 } centimeters & 0.3937 & inches \\
meters & 3.2808 & feet \\
kilometers & 0.6214 & miles (statute) \\
newtons & 0.2248 & pounds (force) \\
kilopascals & 0.1450 & pounds per square inch \\
meter-newtons & 0.7375 & foot-pounds
\end{tabular}

British units of measurement used in this report can be converted to metric units as follows:

Multiply

miles (U. S. statute)

tons (2000 Ib)

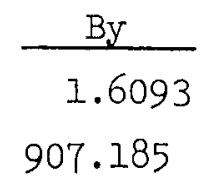

907.185
To Obtain

kiIometers

kilograms 



\section{Summary}

A technique based on the U. S. Army Engineer Waterways Experiment Station mobility prediction system was developed for predicting power requirements as a function of system output (pull coefficient) for a given wheel equipped with a pneumatic tire operating on clay and in a range from towed to 20 percent slip. In addition, separate relations of system output and system input (torque coefficient) as functions of slip can be predicted. Comparisons with data from vehicle field tests show fair to good agreement between measured and predicted performance parameters. 


\section{Introduction}

1. For more than 10 years, under the sponsorship of the U. S. Army Materiel Command, mobility researchers at the U. S. Army Engineer Waterways Experiment Station (WES) have studied the performance of tires on soft soils. The primary result of these studies is a system for predicting maximum drawbar pull (system output), torque (system input) required to generate maximum pull, and towed force (zero torque) for several running gear-soil systems, e.g. pneumatic tires on fine- and coarse-grained soils. Stimulated by recent WES investigations for the National Aeronautics and Space Administration of the power required by the Lunar Roving Vehicle on the Apollo 15 and subsequent missions, 1 mobility researchers are taking a new look at power requirements for terrestrial vehicles in off-road situations.

2. In the study reported herein a system was developed for predicting not only the maximum pull that can be developed by a powered wheel on fine-grained soils and the force required to tow it, but also the pull and power required over its full range of operating conditions, i.e. from towed to maximum pull. This prediction system is based on the results of carefully controlled laboratory tests with single wheels operating on clay of various consistencies. The wheels were equipped with tires of various sizes, and were tested under several loads. In addition, an attempt was made to compare results predicted by this system with results from field tests with wheeled vehicles.

\section{Basic Concept}

3. Usually, the relations between certain performance parameters and slip* for a single wheel equipped with a pneumatic tire are

\footnotetext{
* Slip is defined as $\left(v_{\mathrm{W}}-\mathrm{v}_{\mathrm{a}}\right) / \mathrm{v}_{\mathrm{W}}$, where $\mathrm{v}_{\mathrm{W}}=$ wheel speed, and $v_{a}=$ test carriage or vehicle speed.
} 
determined in a series of constant-slip tests conducted at various slip levels, or in one programmed-slip test. The latter type of test, which was used in this study, is started when the wheel is in the negative slip range, i.e. the translational speed of the test carriage is greater than that of the wheel. The wheel speed is held constant, and the carriage is slowed at a programmed, uniform rate to cause the wheel to pass through the towed condition (torque $=0$ ), the zero percent slip condition (carriage speed = wheel speed), the self-propelled condition (pull $=0$ ), etc., as slip is progressively increased to 100 percent (carriage speed $=0)$.

4. Two performance parameters of interest in this study were the pull coefficient $\mathrm{P} / \mathrm{W}$ (pull $\mathrm{P}$ developed by the wheel-soil system divided by the wheel load $W$ ) and torque coefficient $M / W r$ a (torque $M$ required to develop a certain pull divided by the product of wheel load $\mathrm{W}$ and active radius of the wheel $r_{\mathrm{a}}$ ). Relations of $\mathrm{P} / \mathrm{W}$ and $\mathrm{M} / \mathrm{Wr}{ }_{\mathrm{a}}$, respectively, to slip from a representative programmed-slip test on clay are shown in fig. 1 .

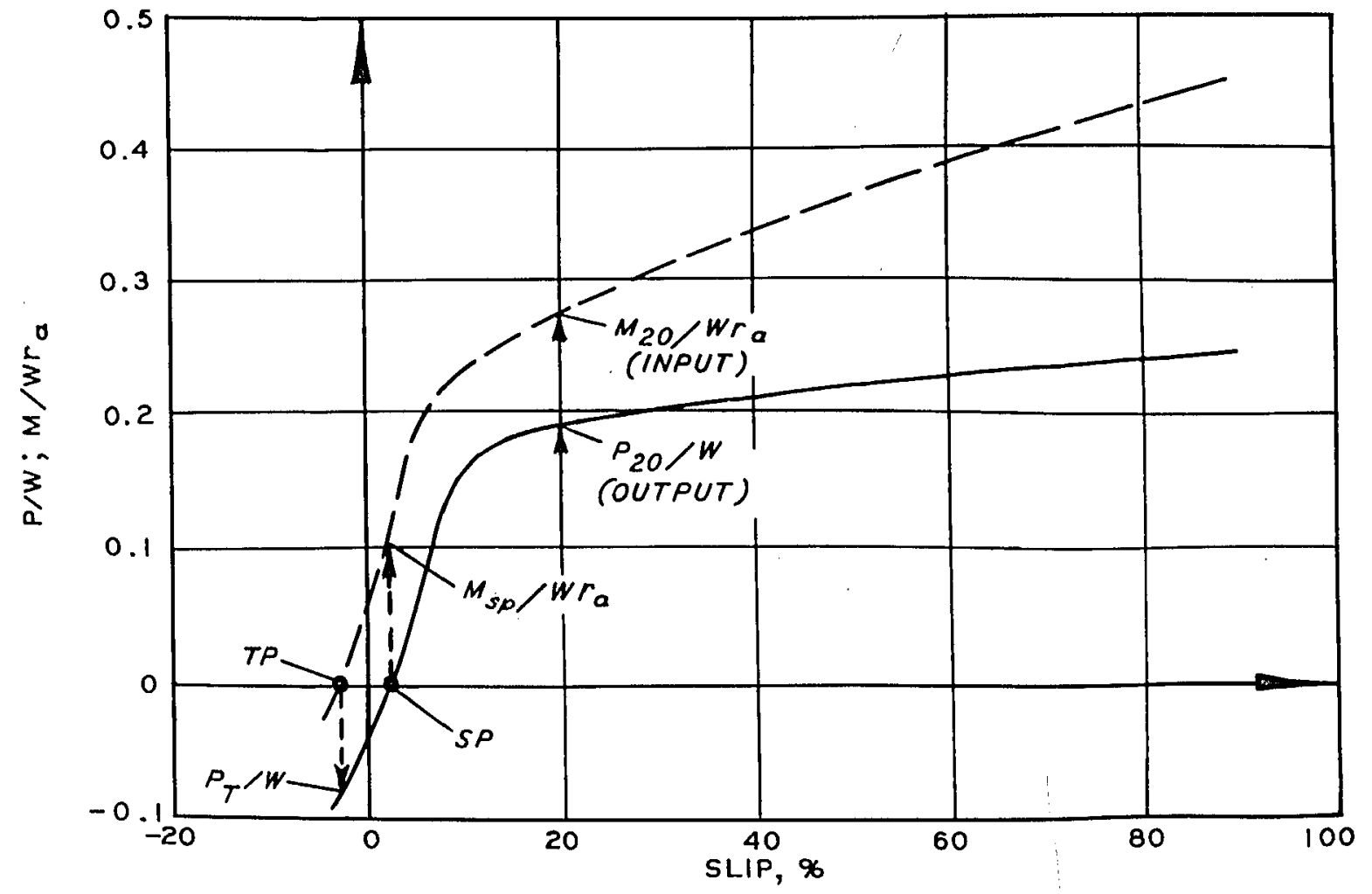

Fig. 1. Representative relations of torque and pull coefficients to slip ( $T P=$ towed condition, $\mathrm{SP}=$ self-propelled condition) 


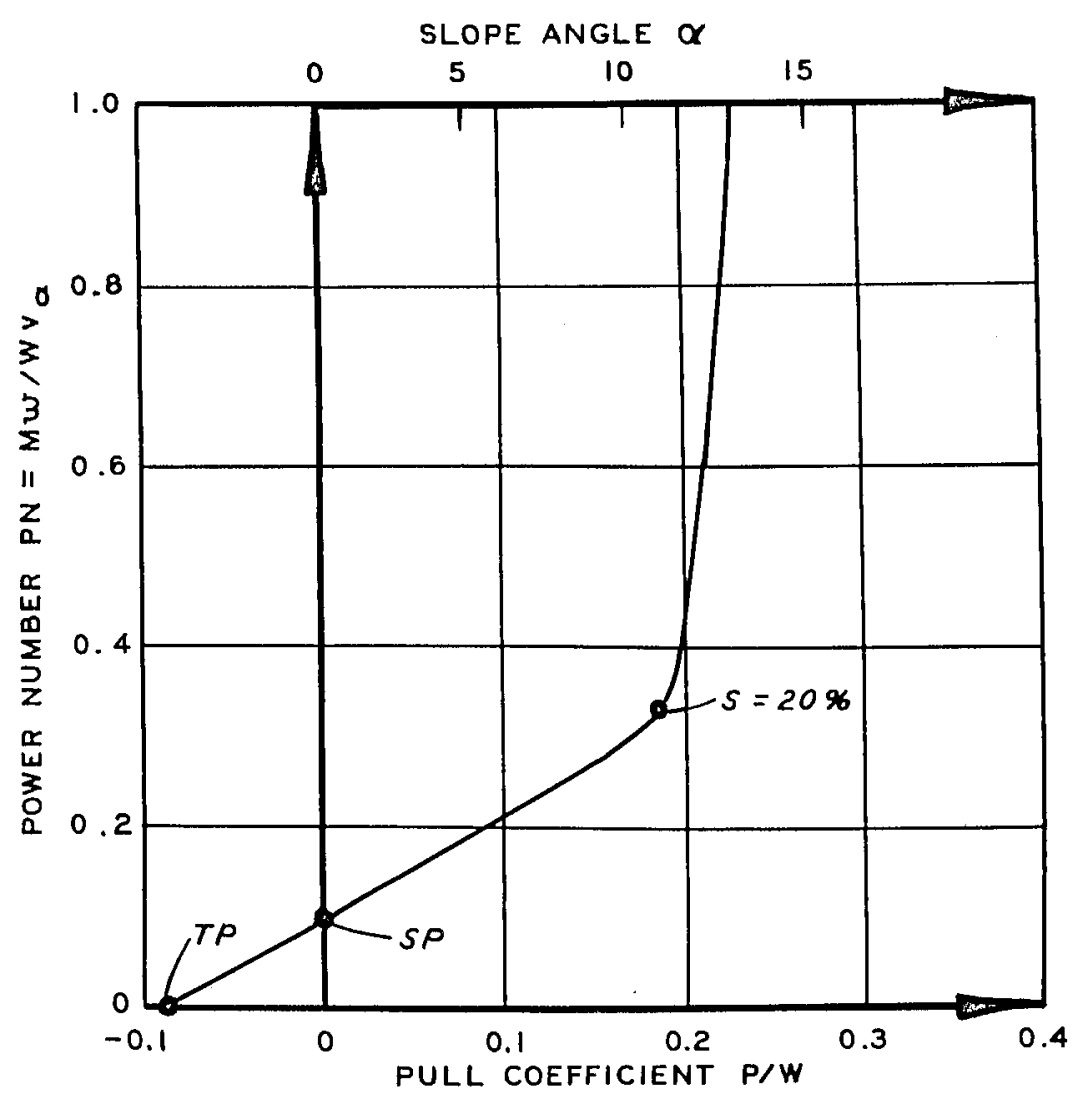

Fig. 2. Representative relation of power number to pull coefficient and/or slope angle

5. The two relations, $\mathrm{M} / \mathrm{Wr}$ a and $\mathrm{P} / \mathrm{W}$ versus slip, can be incorporated into a new relation by introducing the dimensionless power number $P N$ as a third variable resulting in $P N=\mathrm{M \omega} / \mathrm{Wv} \mathrm{a}_{2}$ (where $\omega$ $=$ rotational velocity of the wheel $=v_{\mathrm{w}}\left(\mathrm{r}_{\mathrm{a}}\right)$. PN is plotted in fig. 2 versus $P / W$. This relation expresses the energy consumed per unit distance per unit of wheel or vehicle weight for a certain system output. The relation of PN to slope angle $\alpha$, plotted on the upper abscissa in fig. 2, reflects the assumption that $\mathrm{P} / \mathrm{W}$ measured at a given slip on a level surface with a single wheel is approximately equivalent to the tangent of the angle of the slope that a vehicle equipped with similar wheels can climb.

6. The relation between $\mathrm{PN}$ and $\mathrm{P} / \mathrm{W}$ is of particular importance to the vehicle designer or to the user who must plan the mission of a certain vehicle in military field operations. Towed force and power number for the self-propelled condition can be identified simply 
(fig. 2). The pull coefficient at 20 percent slip $\left(\mathrm{P}_{20} / \mathrm{W}\right)$, often referred to as "maximum pull coefficient," characterizes a limiting condition, because any system output beyond this point consumes excessive power. Also, for any given value of $\mathrm{P} / \mathrm{W}$, the power consumption rate (PCR) in whr $/ \mathrm{km}^{*}$ for the interaction of a given wheel or vehicle with the soil can be obtained by multiplying the corresponding power number by the corresponding wheel or vehicle weight, expressed in newtons, and the fraction 1/3.6. Expressed in equation form:

$$
\begin{aligned}
& \mathrm{PCR}=\frac{\mathrm{PN}}{3.6} \times \mathrm{W} \\
& \mathrm{PCR}=\mathrm{PN} \times \frac{1000 \mathrm{~m}}{\mathrm{~km}} \times \frac{\mathrm{hr}}{3600 \mathrm{sec}} \times \text { newtons } \\
& \mathrm{PCR}=\mathrm{PN} \times \frac{1000}{3600} \times \frac{\mathrm{m}-\mathrm{N}}{\mathrm{sec}} \times \frac{\mathrm{hr}}{\mathrm{km}}
\end{aligned}
$$

Since $P N$ is dimensionless and a watt is torque per unit time, $1 \mathrm{w}=1 \mathrm{~m}-\mathrm{N} / \mathrm{sec}$; therefore

$$
\dot{P} C R=\frac{P N}{3.6} \times W=\frac{\mathrm{Whr}}{\mathrm{km}}=2.15 \times 10^{-3} \frac{\mathrm{hp}-\mathrm{hr}}{\mathrm{mile}}
$$

7. Because of the importance of the relation between $P N$ and $\mathrm{P} / \mathrm{W}$, the development of a technique for its prediction is the main topic of this report. In addition, the use of this technique, once established, in predicting $\mathrm{P} / \mathrm{W}$ and $\mathrm{M} / \mathrm{Wr}$ a versus $\mathrm{slip}$ will be shown.

8. The WES "clay mobility number" $\mathrm{N}_{\mathrm{c}}$ was used in developing the prediction technique:

$$
\mathrm{N}_{\mathrm{c}}=\frac{\mathrm{Cbd}}{\mathrm{W}}\left(\frac{\delta}{\mathrm{h}}\right)^{1 / 2} \frac{1}{1+\frac{\mathrm{b}}{2 \mathrm{~d}}}
$$

where

$\mathrm{C}=$ average cone penetration resistance of the 0 - to $15-\mathrm{cm}$ soil layer as measured with the WES standard cone penetrometer

* A table of factors for converting metric to British and British to metric units of measurement is given on page vi $i$. 
$\mathrm{b}=$ unloaded tire section width

$\mathrm{d}=$ unloaded tire diameter

$W=$ vertical load applied to the tire through the axle

$\delta=$ tire deflection; i.e. difference between unloaded and loaded section heights

$\mathrm{h}=$ unloaded tire section height

9. The clay mobility number was developed by means of dimensional analysis to predict the performance of tires with circular cross sections. ${ }^{2}$ It was subsequently modified to the form shown above to allow prediction of the performance of rectangular-section tires. 3 Tests were conducted with nine different pneumatic tires under a broad range of wheel loads and tire deflections. The soil was a fat clay ( $\mathrm{CH}$ ) prepared to various consistencies. Relations were established between the clay mobility number and the following performance parameters: pull coefficient $(\mathrm{P} / \mathrm{W})$, torque coefficient $\left(\mathrm{M} / \mathrm{Wr}_{\mathrm{a}}\right)$, sinkage coefficient ( $\left.\mathrm{z} / \mathrm{d}\right)$, all at 20 percent slip, and towed force coefficient $\left(\mathrm{P}_{\mathrm{T}} / \mathrm{W}\right)$. These relations are displayed in fig. 3, except that between sinkage coefficient and

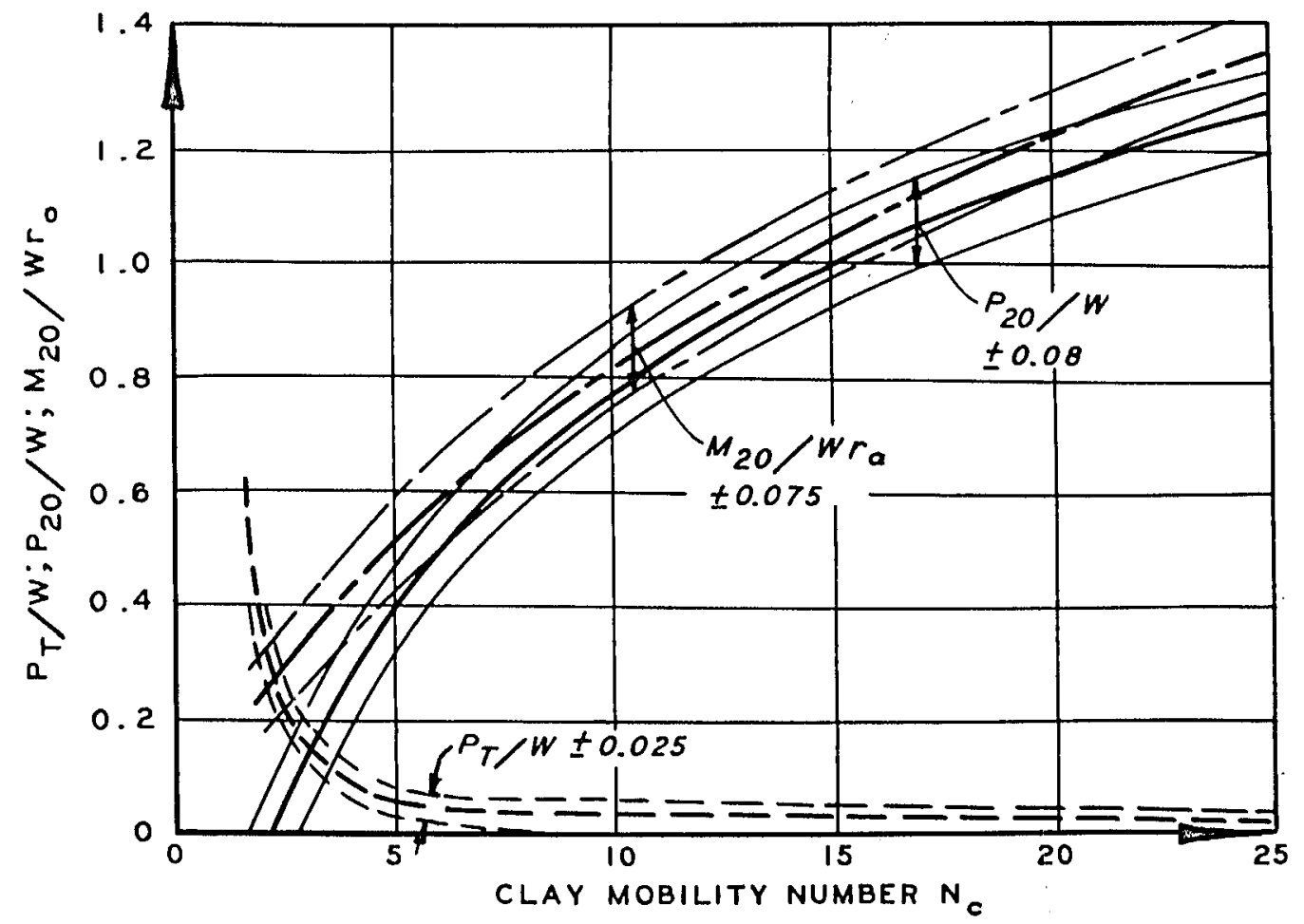

Fig. 3. Performance coefficients versus clay mobility number (adapted from reference 3) 
clay mobility number; sinkage is not treated in this study. These relations allow the prediction of the performance parameters under consideration for pneumatic tires operating at two extreme performance conditions: towed and 20 percent slip. These conditions are important from the soft-soil mobility viewpoint because they describe the Iower limit and, for all practical purposes, the upper limit of the operational range of a wheel (fig. 1). Also, the two points on the PN versus $\mathrm{P} / \mathrm{W}$ curve (fig. 2) can be predicted.

10. The performance relations cannot be predicted with the system described above, however, for the full range of conditions between towed and 20 percent slip. Therefore, relations between $\mathrm{PN}$ and $\mathrm{P} / \mathrm{W}$ for intermediate slip conditions ( 0 to 20 percent) and for different values of the clay mobility numbers had to be established. Once established, they were combined to form another prediction technique, whereby not only $P N$ versus $P / W$ but also $P / W$ versus slip and $M / W r a$ versus slip could be predicted for a given pneumatic tire-soil system.

\section{Development of Expanded Prediction System}

11. The data used for the development of the expanded prediction system were those used by Turnage 3 in establishing the performance prediction curves for the towed and the 20 percent slip conditions. The following single tires were tested in the laboratory:

\begin{tabular}{|c|c|c|c|}
\hline Tire Size & $\begin{array}{l}\text { Approximate Shape } \\
\text { of Cross Section }\end{array}$ & $\begin{array}{l}\text { Width } \\
\mathrm{b}, \mathrm{cm}\end{array}$ & $\begin{array}{l}\text { Diameter } \\
\mathrm{d}, \mathrm{cm}\end{array}$ \\
\hline $4.00-7,2-P R$ & Circular & 11 & 36 \\
\hline $4.00-20,2-P R$ & Circular & 11 & 71 \\
\hline $6.00-16,2-P R$ & Circular & 17 & 72 \\
\hline $9.00-14,2-P R$ & Circular & 21 & 72 \\
\hline $16 \times 6.50-8,2-P R$ & Rectangular & 16 & 41 \\
\hline $16 \times 11.50-6,2-P R$ & Rectangular & 28 & 44 \\
\hline $16 \times 15.00-6,2-P R$ & Rectangular & 39 & 44 \\
\hline $26 \times 16.00-10,4-P R$ & Rectangular & 41 & 62 \\
\hline $31 \times 16.50-13,4-P R$ & Rectangular & 38 & 75 \\
\hline
\end{tabular}

12. Test loads ranged from about 1000 to $5400 \mathrm{~N}$, with tire deflections $\delta / \mathrm{h}$. from 0.08 to 0.35 . The average cone penetration resistance 
$\mathrm{C}$ of the test clay ranged from 55 to $470 \mathrm{kPa}$, with corresponding relative consistencies ranging from very soft to medium stiff. These values, together with values for corresponding tire geometry and loading conditions, resulted in clay mobility numbers from 2 to 10 . Thus, the system was restricted to an area where the worst performance conditions and the most drastic changes in the performance parameters $\mathrm{P}_{20} / \mathrm{W}, \mathrm{M}_{20} / \mathrm{Wr} a$, and $\mathrm{P}_{\mathrm{T}} / \mathrm{W}$ would occur (fig. 3 ).

13. Power numbers and pull coefficients were extracted for each test at slips of 5, 7.5, 10, and 15 percent, and at the self-propelled condition. Relations between $\mathrm{PN}$ and $\mathrm{N}_{c}$, and between $\mathrm{P} / \mathrm{W}$ and $\mathrm{N}_{c}$ for these conditions were developed by plotting curves of best fit through the data points. As an example, fig. $4 a$ shows the relation between $N_{c}$ and $P N$ at the self-propelled condition ${ }^{P N}{ }_{s p}$. In addition, the slip at which the self-propelled condition occurred $\mathrm{s} s$ is presented as a function of $N_{c}$ ( $f i g .4 b$ ) for reasons that will be explained later. $\mathrm{P} / \mathrm{W}$ and $\mathrm{PN}$ versus $\mathrm{N}_{\mathrm{c}}$ for 7.5 percent slip are displayed in figs. $5 \mathrm{a}$ and $5 \mathrm{~b}$, respectively.

14. With the five relations mentioned above, together with the existing prediction relations for the towed and the 20 percent slip conditions (fig. 3), a nomograph was established that shows PN as a function of $\mathrm{N}_{\mathrm{c}}, \mathrm{P} / \mathrm{W}$ or slope-climbing capability, and wheel slip (fig. 6). From a given power number at a specific slip, the corresponding torque coefficient (system input) can be derived as follows:

$$
P N=\frac{M \omega}{W v_{a}}=\frac{M v_{W}}{W_{a} v_{a}}
$$

With $s=1-\left(v_{a} / v_{w}\right)$

$$
\mathrm{PN}=\frac{\mathrm{M}}{\mathrm{Wr}} \times \frac{1}{(1-\mathrm{s})}
$$

and.

$$
\frac{M}{W r_{a}}=P N(I-s)
$$




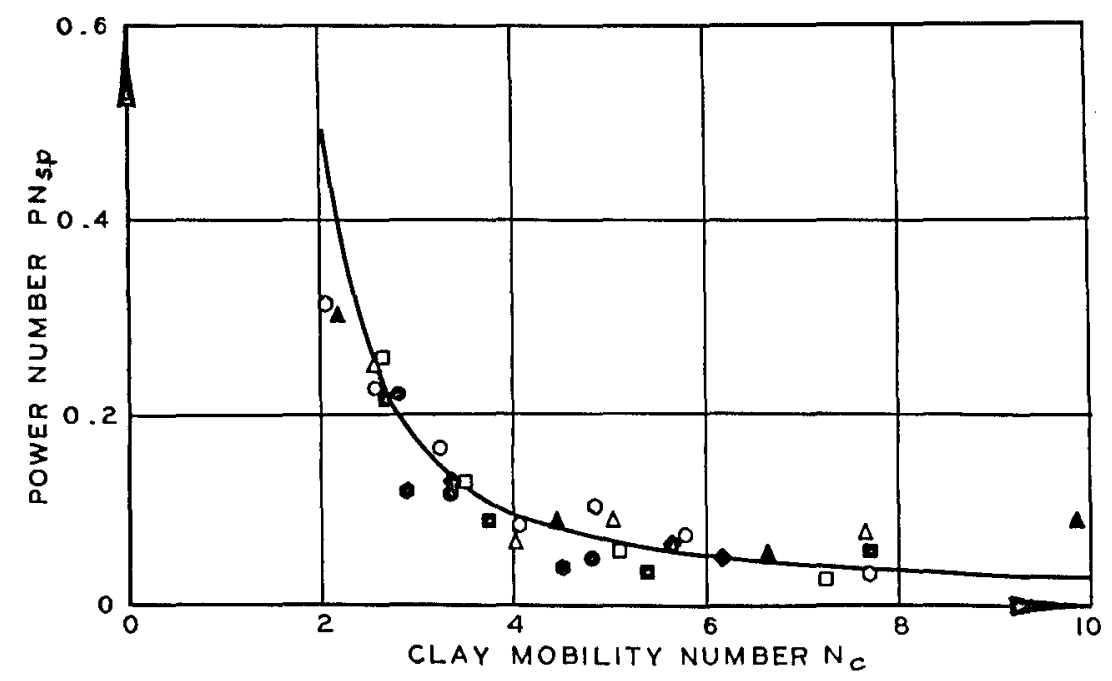

a. POWER NUMBER

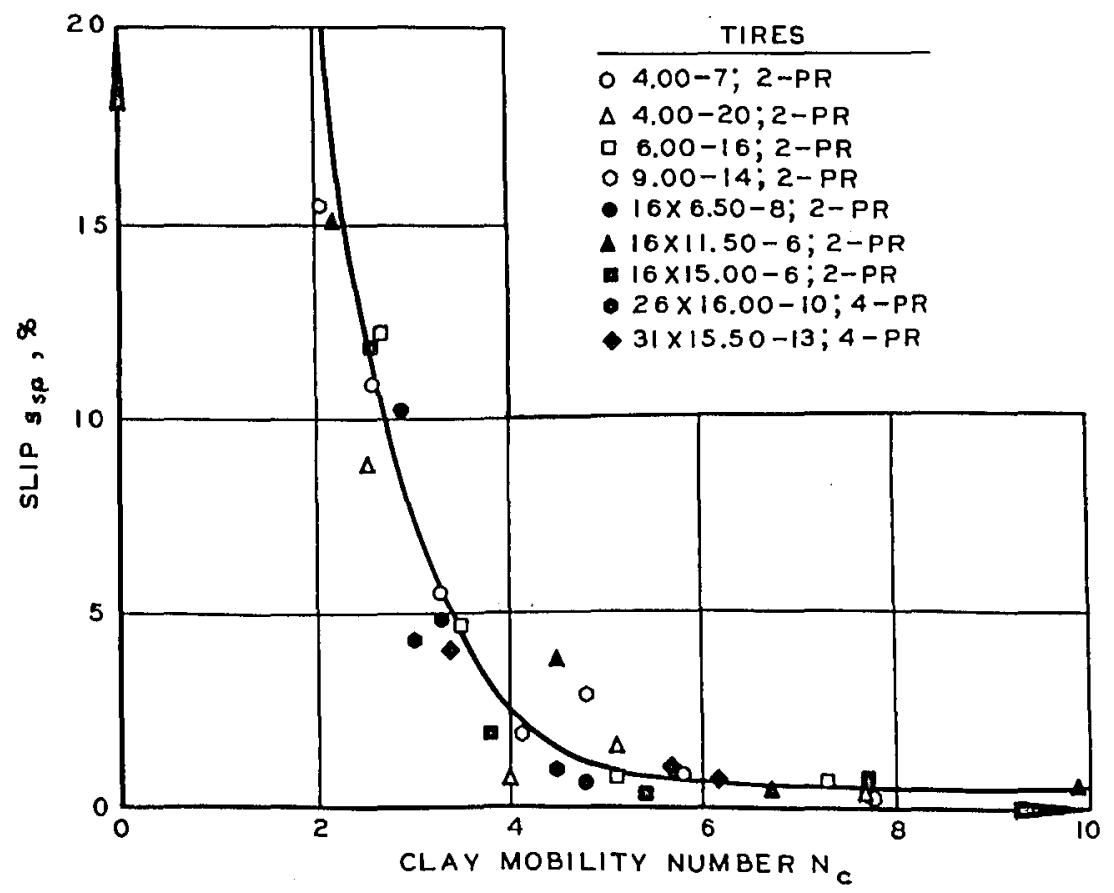

b. SLIP

Fig. 4. Relations of power number and slip for self-propelled condition to clay mobility number 


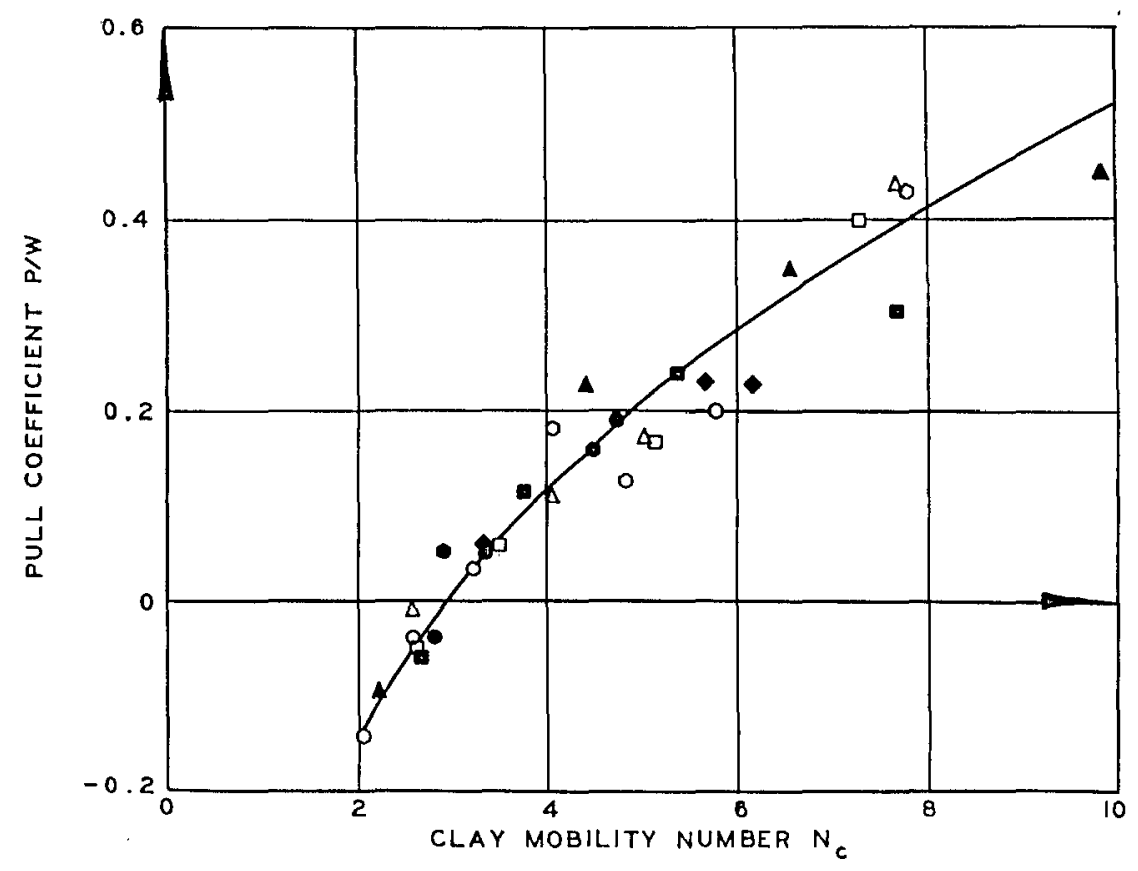

a. PULL COEFFICIENT

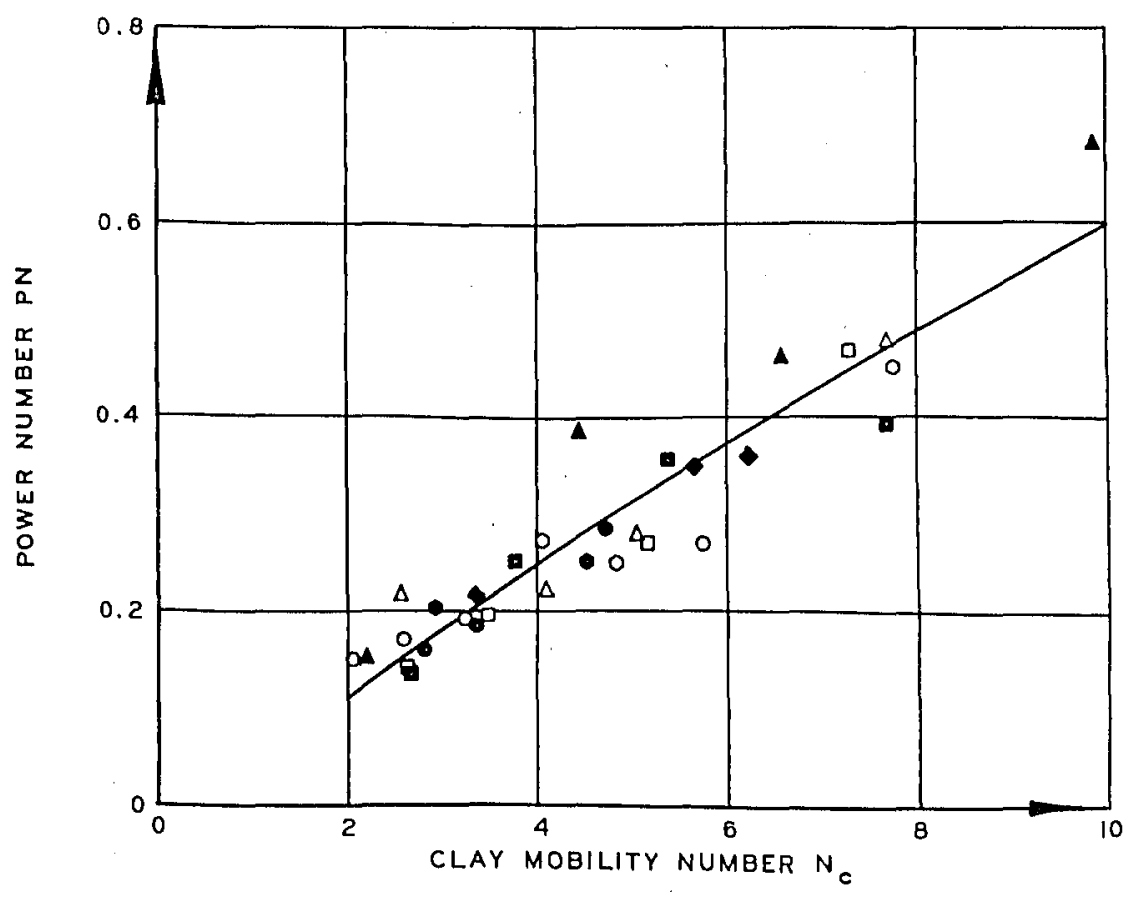

b. POWER NUMBER

Fig. 5. Relations of pull coefficient and power number for 7.5 percent slip to clay mobility number

(for legend see fig. 4) 


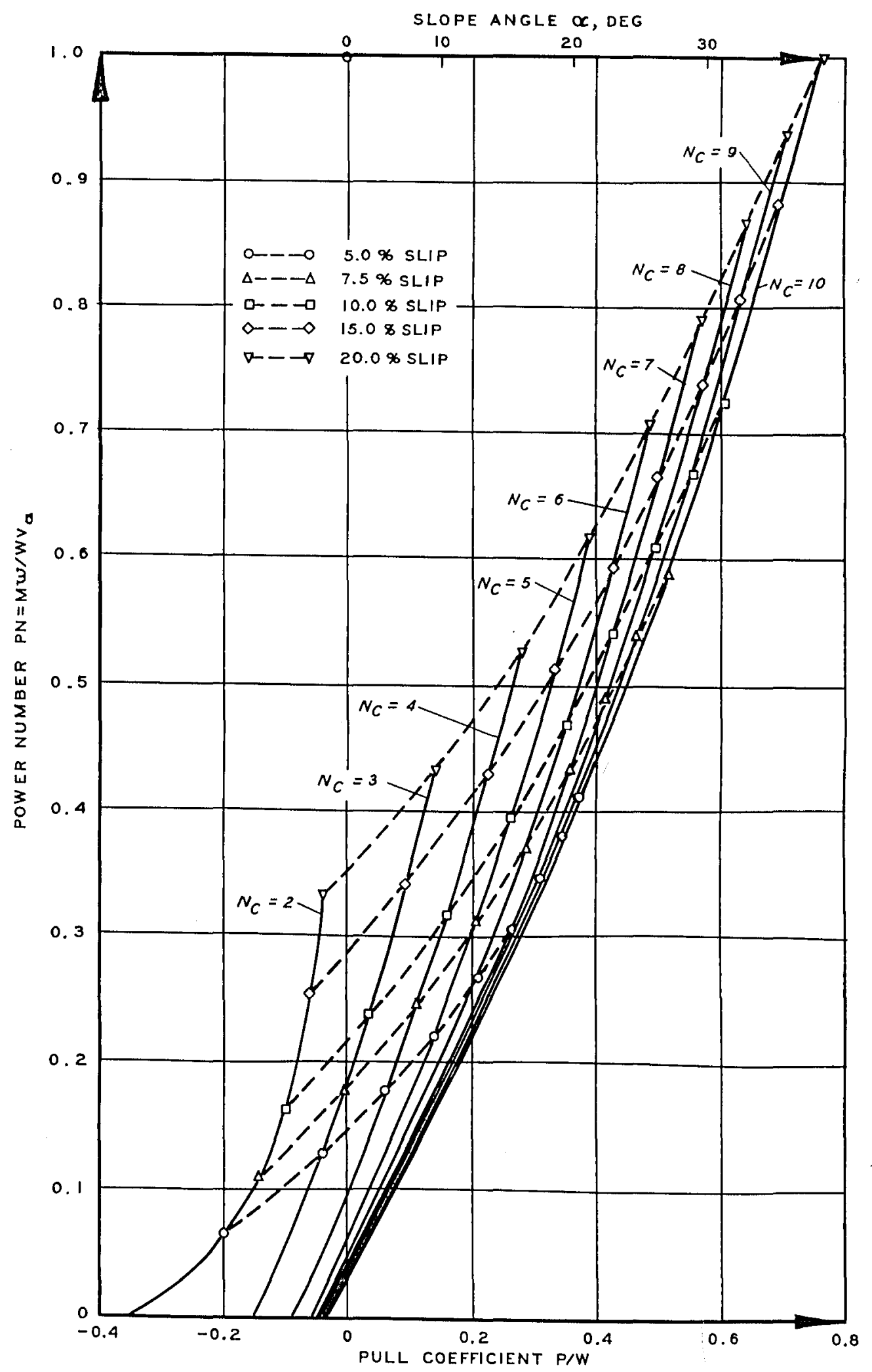

Fig. 6. Power number as function of pull coefficient, slope angle, slip, and clay mobility number 
When $\mathrm{PN}_{\mathrm{Sp}}$ occurs at slips smaller than 5 percent, i.e. $\mathrm{M}_{\mathrm{sp}} / \mathrm{Wr} \mathrm{a}$, and the location of $\mathrm{P} / \mathrm{W}=0$ on the slip axis cannot be determined from fig. 6, the relation between slip at the self-propelled point and the clay mobility number can be determined from fig. $4 \mathrm{~b}$.

15. Therefore, for any clay mobility number between 2 and 10 , i.e. for a certain tire under a given load on a given soil condition, not only the relation between power number or power consumption rate and system output can be established, but also the system output and system input as functions of slip can be determined by means of fig. 6 and, if necessary, fig. $4 \mathrm{~b}$.

\section{Application of Prediction System to Vehicle Field Data}

16. The purpose of this discussion is not to validate the prediction system, but to demonstrate its applicability to vehicle test data. At present, no attempt is made to alter the system to make the predicted data agree with the field data.

17. The field data considered here were obtained from the "MEXA Program." 4 only tests that had been conducted on clay classified as $\mathrm{CH}$ were selected; thus, the soil was similar to that used in developing the prediction system.

M35A2 truck

18. The first example is taken from one-pass drawbar-pull tests with an M35A2, 2-1/2-ton, $6 \times 6$ military truck equipped with 11.00-20 single tires. Average cone penetration resistance $\mathrm{C}$ for the 0 - to 15-cm soil layer was $771 \mathrm{kPa}$, which corresponds to a stiff soil consistency. This value for $\mathrm{C}$, together with the corresponding tire geometry and loading condition, results in a clay mobility number $\mathbb{N}_{C}$ of 7.6 .

19. With $N_{c}=7.6$, the corresponding relation between $P N$ and $\mathrm{P} / \mathrm{W}$ was obtained from fig. 6 and compared with the values measured in the field (fig. 7). Note that the power consumption rate is also considered in fig. 7. The comparison shows a relatively good agreement 


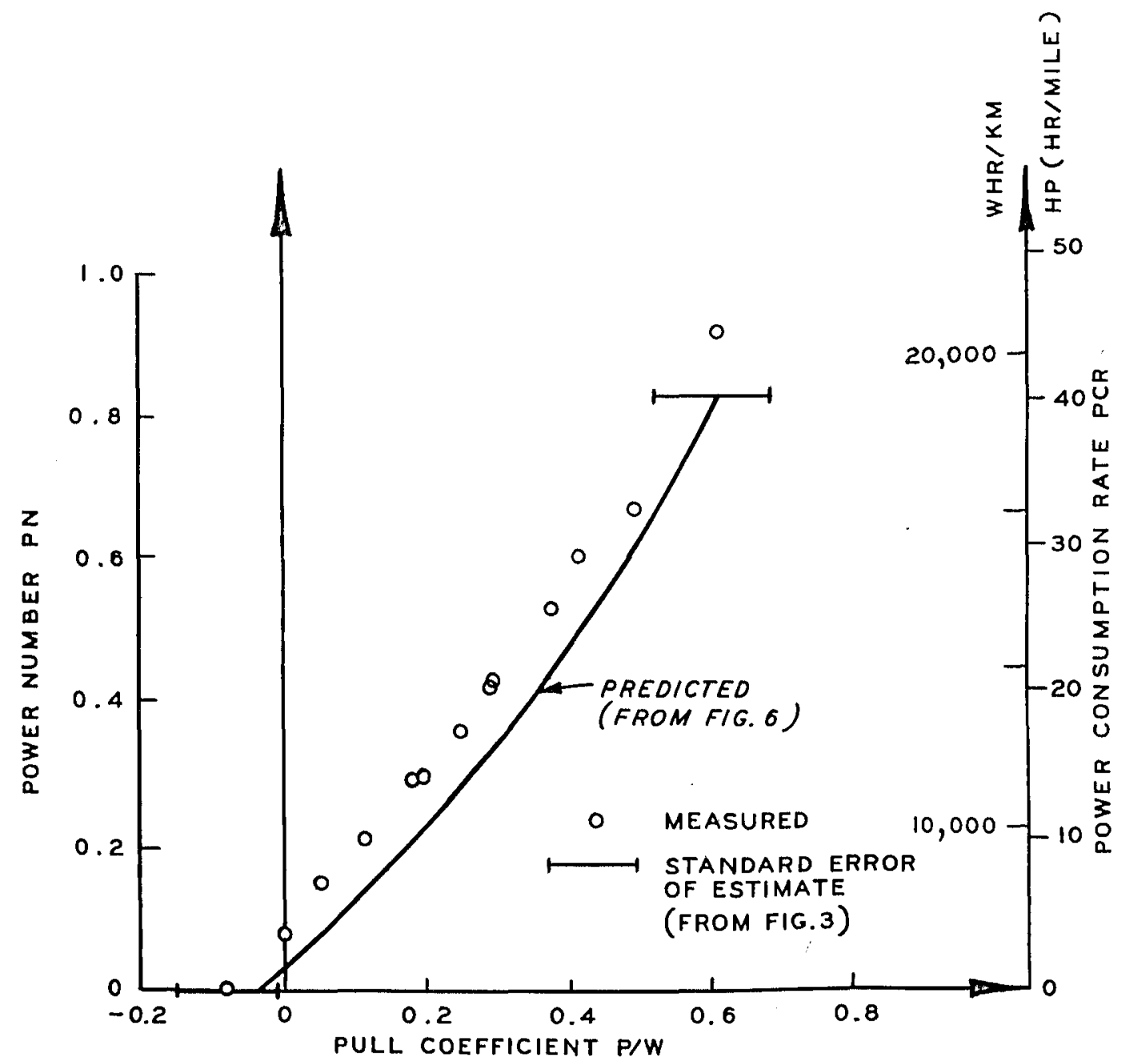

Fig. 7. Comparison of measured and predicted power requirements for an M35A2 truck.

between measured and predicted values, especially if the scatter band on the prediction curve indicated by the standard errors of estimate as given by Turnage 3 for the towed and the 20 percent slip conditions is considered.

20. To complete this example, $\mathrm{P} / \mathrm{W}$ and $\mathrm{M} / \mathrm{Wr}$ a functions of . slip were determined (fig. 8) from fig. 4b, fig. 6, and the relation between $\mathrm{PN}$ and $\mathrm{M} / \mathrm{Wr} \mathrm{a}_{\mathrm{a}}$, as derived above. The comparison shows that the predicted $\mathrm{P} / \mathrm{W}$ values are slightly larger for a given slip than the measured values ( $\mathrm{fig}$. 8a), whereas an almost perfect agreement is achieved in the case of the measured and predicted $\mathrm{M} / \mathrm{Wr}$ a versus $\mathrm{slip}$ relations (fig. 8b). 


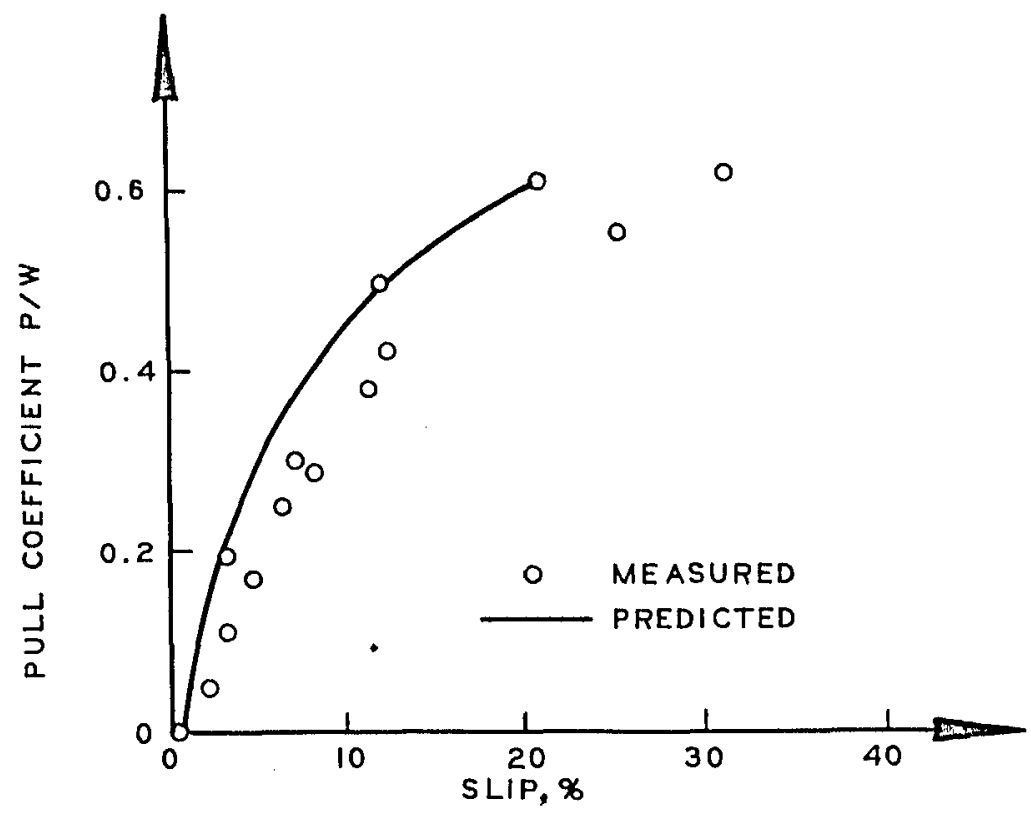

a. PULL COEFFICIENT

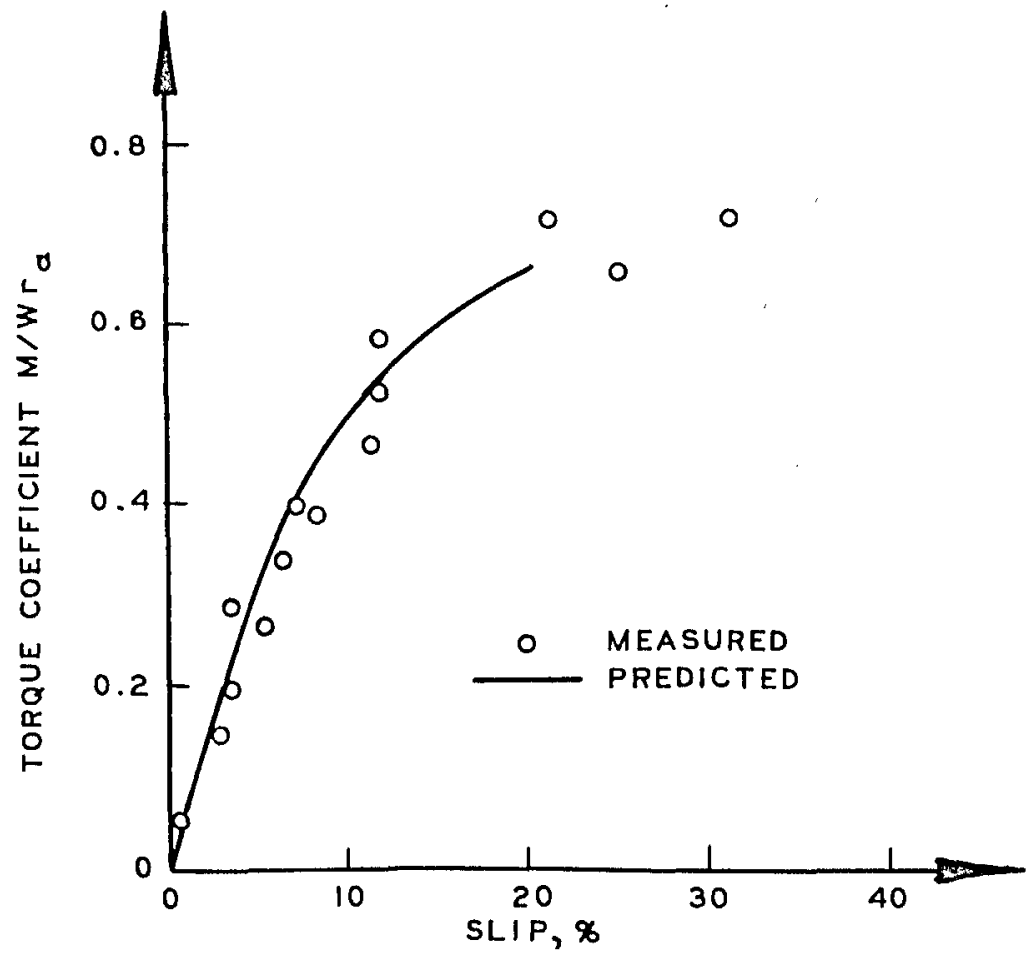

b. TORQUE COEFFICIENT

Fig. 8. Comparison of measured and predicted relations of pull and torque coefficients to slip for an M35A2 truck 
MEXA 10xlo vehicle

21. The second example is taken from one-pass drawbar-pull tests with the MEXA 2-1/2-ton, 10x10 truck equipped with 42x40-16A tires. Four test series conducted on the same test area were combined for this analysis. Cone penetration resistance for the $0-$ to $15-\mathrm{cm}$ soil layer ranged from 110 to $159 \mathrm{kPa}$ in the four series. The average value, $131 \mathrm{kPa}$, corresponds to a very soft soil consistency. The average remolding index $R I$ was 0.64 , with corresponding remolded cone penetration resistance $\mathrm{RC}$ of $83 \mathrm{kPa}$. RI represents a measure of the deformability characteristics of soft soils during multipass traffic. Because of the extremely soft soil encountered during these tests, RC was used in this example instead of $\mathrm{C}$.

22. With $\mathrm{RC}=83 \mathrm{kPa}$ and the corresponding tire geometry and loading condition, $\mathbb{N}_{c}=3.5$ was obtained. The relation between PN and $P / W$ derived with $N_{c}=3.5$ from fig. 6 is shown in fig. 9, together with the measured values from the field tests. Over the full range of system output, the power requirements in most cases are predicted higher for a given $\mathrm{P} / \mathrm{W}$ than they were measured. However, the instrumentation for measuring torque during the tests was not quite satisfactory, i.e. torque was not measured directly at the axles, which may account for the deviation of most of the measured values from the predicted values.

MEXA 8x8 vehicle

23. The third example is taken from one-pass drawbar-pull tests with the MEXA 2-1/2-ton, $8 \times 8$ truck equipped with 48x31-16A tires. Results from two test series conducted in the same area were combined for this analysis, which must be restricted to the prediction of $P / W$ versus slip, since torque values were not reported. Cone penetration resistance $\mathrm{C}$ was 145 and $158 \mathrm{kPa}$, respectively, for the two series with an average of $151 \mathrm{kPa}$, which corresponds to a very soft soil consistency. The average $R I$ was 0.62 with an $R C$ of $93 \mathrm{kPa}$. This latter value was used in this example for the same reason stated in paragraph 21.

24. An RC of $93 \mathrm{kPa}$, together with the tire geometry and the 


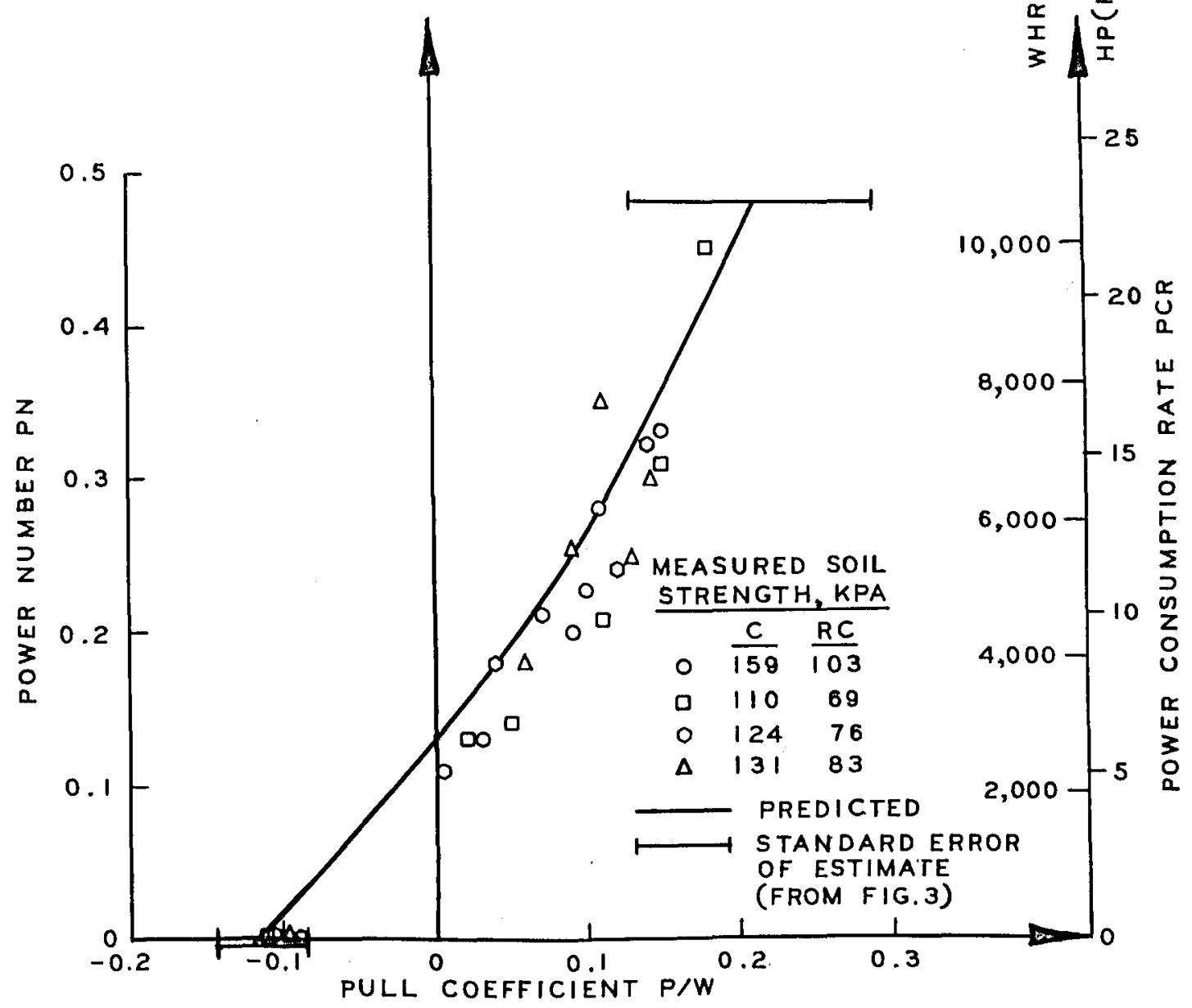

Fig. 9. Comparison of measured and predicted power requirements for MEXA 10x10 truck

loading condition for the vehicle, resulted in a clay mobility number of 2.9. The relation between $P / W$ and slip, as derived from fig. 6, is compared in fig. 10 with the measured field data.

\section{Conclusions and Recommendation}

25. It is concluded that:

a. Power requirements as a function of pull coefficient can be predicted by the technique developed in this study for a given wheel equipped with a pneumatic tire operating on clay and in a range from towed to 20 percent slip. 


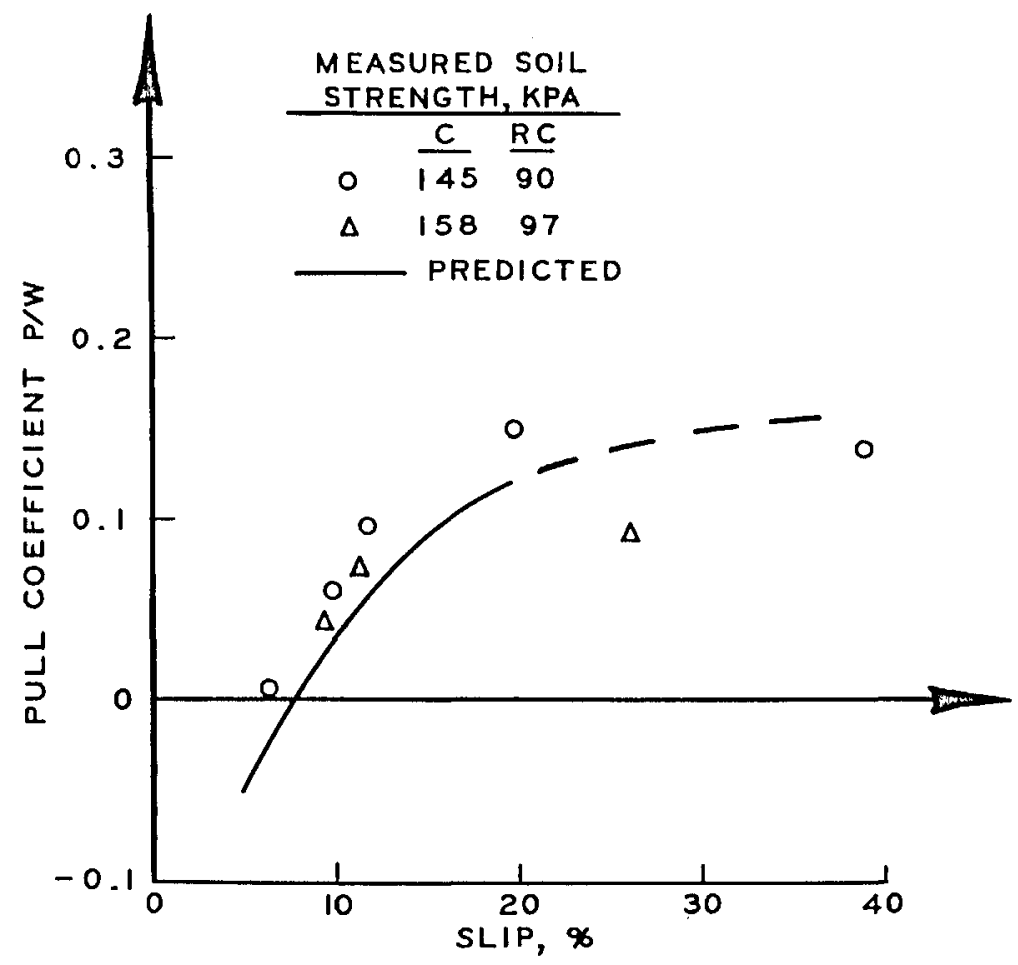

Fig. 10. Comparison of measured and predicted relations of pull coefficient to slip for MEXA

$8 \times 8$ truck

b. Relations of pull coefficient and torque coefficient as functions of slip can be predicted for the pneumatic tire mentioned above in a.

c. The prediction system developed herein can be used to predict wheeled-vehicle field performance with fair to good accuracy.

26. It is recommended that a technique similar to that developed in this study be developed for wheels operating in coarse-grained soils.

\section{Literature Cited}

1. Freitag, D. R., et al., "Wheels for Iunar Vehicles," Journal of Terramechanics, Vol 8, No. 3, 1972, pp 89-105.

2. Freitag, D. R., "A Dimensional Analysis of the Performance of Pneumatic Tires on Soft Soils," Technical Report No. 3-688, Aug 1965, U. S. Army Engineer Waterways Experiment Station, CE, Vicksburg, Miss. 
3. Turnage, G. W., "Tire Selection and Performance Prediction for OffRoad Wheeled-Vehicle Operations," Proceedings of the Fourth International Conference on Terrain-Vehicle Systems, Stockholm, International Society for Terrain-Vehicle Systems, Vol 1, 1972, p 61.

4. Schreiner, B. G., "Mobility Exercise A (MEXA) Field Test Program; Performance of MEXA and Three Military Vehicles in Soft Soils," Technical Report M-70-11, Report 2, Vol I, Mar 1971, U. S. Army Engineer Waterways Experiment Station, CE, Vicksburg, Miss. 


\section{DOCUMENT CONTROL DATA - R \& D .}

(Security classification of tille, body of abstract and indexing annotation must be entered when the overall report is claselfled i. ORIGINATING ACYIVITY (Corporate author)

U. S. Army Engineer Waterways Experiment Station

Vicksburg, Mississippi 
Unclassified

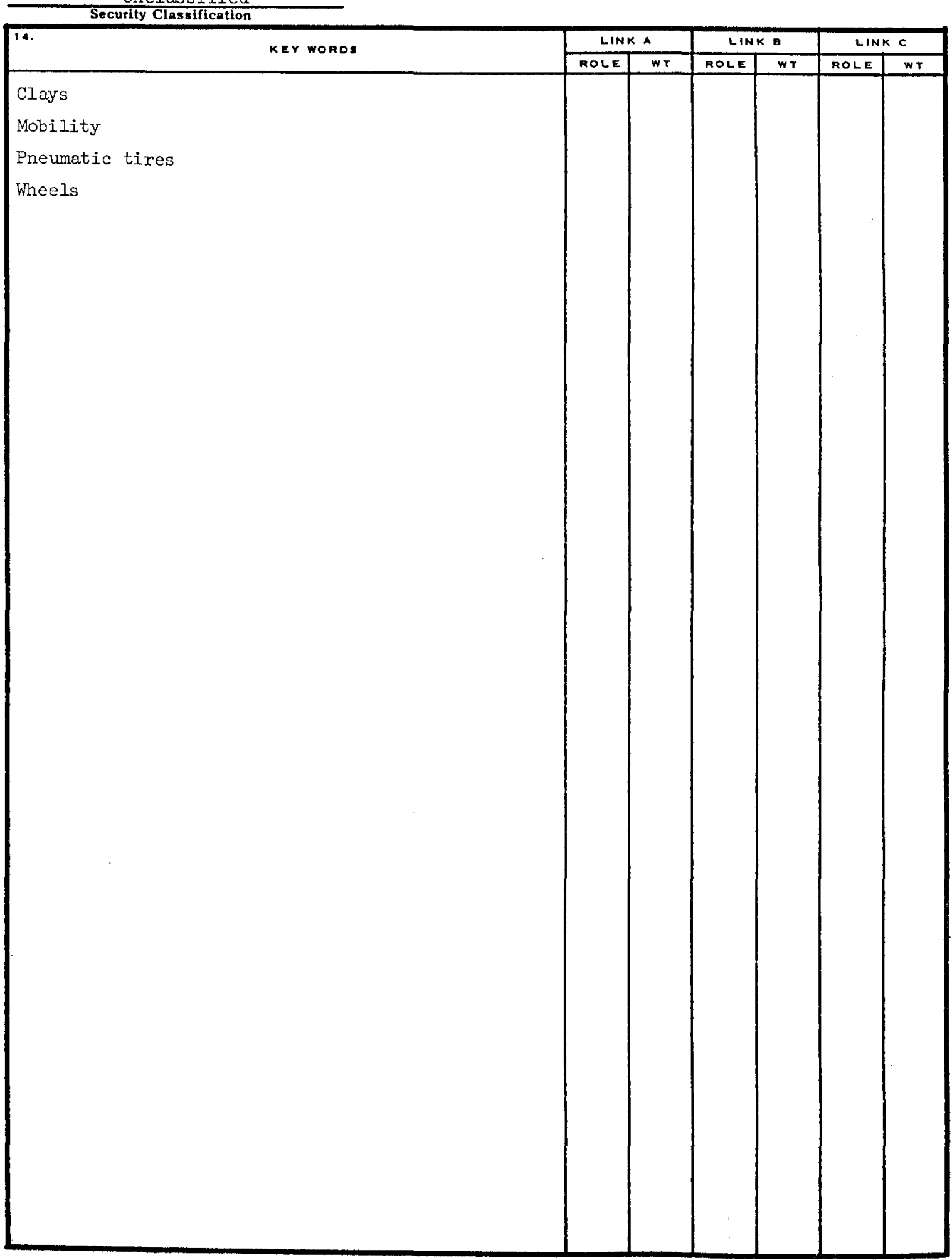

Unclassified

Security Claseification 
